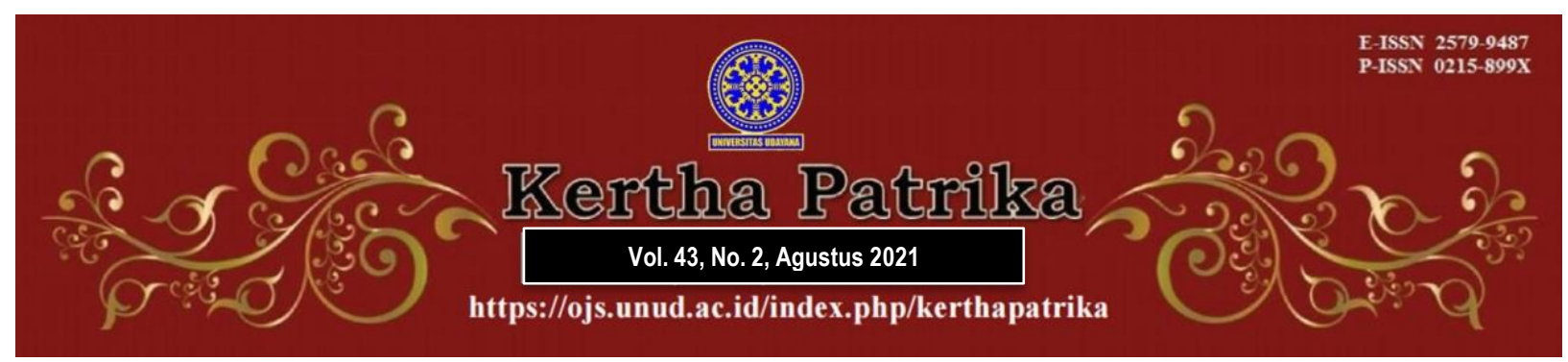

\title{
Menelaah Klaim Republik Korea dan Jepang atas Kepulauan Dokdo atau Takeshima: Pendekatan Historis
}

\author{
Harven Filippo Taufik ${ }^{1}$
}

${ }^{1}$ Fakultas Hukum Universitas Airlangga, E-mail: harventaufik@gmail.com

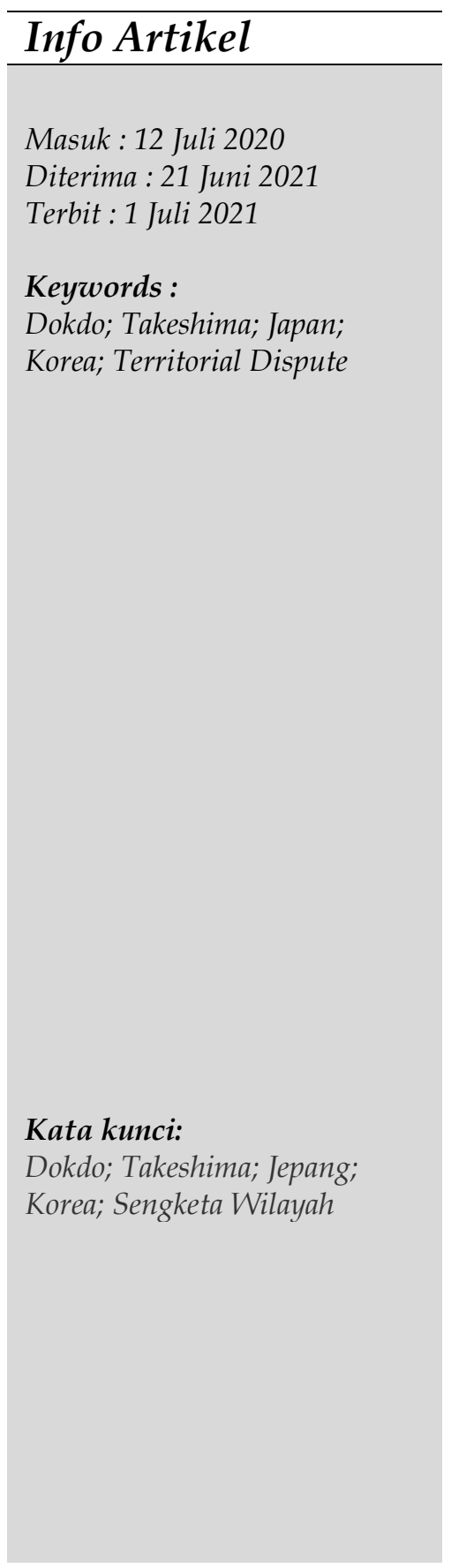

\begin{abstract}
Territory is an inseparable part of the existence of a country. Territory is very important so a territorial disputes between countries may occur. This is the same as happened between the Republic of Korea and Japan. Both countries are disputing a group of islands in the East Sea called Dokdo or Takeshima Islands. The Republic of Korea and Japan both insist that Dokdo or Takeshima Islands are under the sovereignty of their country. Both countries have their respective arguments to support their claims. This research will discuss the arguments of the two countries and analyze them from the perspective of international law. The research method used in this paper is the normative legal research method with historical, case, and conceptual approach. From the research that has been done, it is found that Japan claims the Dokdo Islands is a terra nullius area which was later occupied, and the area is still under its sovereignty under the San Francisco Agreement. However, the Republic of Korea's claim is stronger in the eyes of international law, based on historical facts, actions taken by Korea, existing precedent, and the principle of effectiveness. Based on the principle of effectiveness in international law, the effective control that Korea had exercised so far, even before Japan entered and annexed Dokdo or Takeshima, had broken Japan's terra nullius claim, and confirmed Korea's claim of sovereignty over Dokdo or Takeshima. This is the same as in the case of Sipadan-Ligitan and the case of Palmas Island.
\end{abstract}

\footnotetext{
Abstrak

Wilayah merupakan bagian yang tak terpisahkan dari keberadaan suatu negara. Betapa pentingnya suatu wilayah menyebabkan suatu sengketa wilayah antar negara dapat saja terjadi. Demikianlah yang terjadi antara Republik Korea dan Jepang. Keduanya bersengketa atas suatu wilayah kepulauan di Laut Timur, yaitu Kepulauan Dokdo atau Takeshima. Republik Korea dan Jepang sama-sama bersikeras bahwa Kepulauan Dokdo atau Takeshima berada di bawah kedaulatan negaranya. Keduanya memiliki argumentasi masing-masing terhadap klaim mereka tersebut. Penelitian ini akan membahas argumentasi kedua negara serta menganalisisnya dari sudut pandang hukum internasional. Metode penelitian dalam penulisan ini ialah metode penelitian hukum normatif dengan pendekatan sejarah,
} 
Corresponding Author:

Harven Filippo Taufik, E-mail: harventaufik@gmail.com

DOI :

10.24843/KP.2021.v43.i02.p07 kasus, dan konseptual. Dari penelitian yang telah dilakukan, didapati bahwa Jepang mengklaim Kepulauan Dokdo merupakan wilayah terra nullius yang kemudian diokupasi, serta wilayah tersebut masih dalam kedaulatannya berdasarkan Perjanjian San Fransisco. Akan tetapi, klaim Republik Korea lebih kuat di mata hukum internasional, bila memperhatikan fakta historis, tindakan yang telah dilakukan, preseden yang ada, serta prinsip efektivitas. Berdasarkan prinsip efektivitas dalam hukum internasional, kontrol efektif yang telah dilakukan Korea selama ini, bahkan sebelum Jepang masuk dan menganeksasi Dokdo atau Takeshima, telah mematahkan klaim terra nullius yang dikemukakan Jepang, dan meneguhkan klaim kedaulatan Korea atas Dokdo atau Takeshima. Hal tersebut sebagaimana yang juga berlaku dalam kasus Sipadan-Ligitan dan kasus Pulau Palmas.

\section{Pendahuluan}

Wilayah merupakan hal yang penting bagi eksistensi suatu negara. Menurut Pasal 1 Konvensi Montevideo 1933, salah satu kualifikasi yang harus dimiliki oleh suatu negara adalah wilayah yang tetap. Oleh karena itu, sengketa antar negara mengenai suatu wilayah dapat saja terwujud, sebagaimana yang terjadi antara Republik Korea dan Jepang. Kedua negara tersebut sama-sama menyatakan klaim atas sebuah wilayah yang bernama Kepulauan Dokdo (bagi Korea) atau Takeshima (bagi Jepang). Kepulauan Dokdo atau Takeshima adalah kumpulan pulau-pulau kecil, yang terdiri atas dua batu karang besar dan 33 batu karang lebih kecil, serta meliputi wilayah seluas $0.186 \mathrm{~km} 2 \mathrm{di}$ sebelah selatan Laut Timur atau Laut Jepang1, perbatasan antara Semenanjung Korea dan Jepang. Kepulauan tersebut berada sekitar $88 \mathrm{~km}$ dari Pulau Ulleung (Republik Korea) dan sekitar $158 \mathrm{~km}$ dari Pulau Oki (Jepang). ${ }^{2}$

Sengketa wilayah ini juga berkaitan dengan adanya tumpang tindih Zona Ekonomi Ekslusif (ZEE). Kedua negara tersebut masih belum mampu untuk mencapai kesepakatan mengenai batas ZEE, dan malah memasukkan wilayah yang disengketakan sebagai wilayah masing-masing secara sepihak. Republik Korea sendiri telah mengusulkan mengenai adanya sebuah garis batas wilayah antara Pulau Ulleung (Republik Korea) dan Pulau Oki (Jepang), selebar 60 mil dari garis pantai Semenanjung Korea, yang secara eksplisit memasukkan Kepulauan Dokdo atau Takeshima sebagai wilayah Republik Korea. ${ }^{3}$ Proposal tersebut ditolak sepenuhnya oleh pemerintah Jepang yang juga menyatakan klaimnya terhadap kepulauan tersebut. ${ }^{4}$

1 Ball, D., \& Tanter, R. (2015). The Tools of Owatatsumi: Japan's Ocean Surveillance and Costal Defence Capabilities. Canberra: ANU Press, h. 13.

2 Schwartz, T., \& Yoo, J. (2019). Asian Territorial Disputes and the 1951 San Fransisco Peace Treaty: The Case of Dokdo. Chinese Journal of International Law, 18(3), 503-550. DOI: 10.1093/chinesejil/jmz017. h. 505.

3 Lee, S., \& Dyke, J.M.V. (2010). The 1951 San Fransisco Peace Treaty and Its Relevance to the Sovereignty over Dokdo. Chinese Journal of International Law, 9(4), 741-762. DOI: 10.1093/chinesejil/jmq030. h. 752.

4 Atanassova-Cornelis, E., Pardo, R.P., \& Pejsova, E. (2015). Pride and Prejudice: Maritime Disputes in Northeast Asia. Paris: European Union Institute for Security Studies, h. 17. 
Selain itu, sengketa ini juga semakin memanas dengan adanya kepentingan untuk menguasai potensi kekayaan alam yang ada di Kepulauan Dokdo atau Takeshima. Walaupun belum dilakukan penelitian lebih lanjut mengenai keberadaannya, adanya potensi sumber daya gas alam dasar laut di sekitar kepulauan tersebut juga telah menambah kompleksitas perselisihan. Republik Korea adalah konsumen energi terbesar ke-11 di dunia dan importir minyak terbesar ke-5. Negara tersebut sangat bergantung pada impor minyak untuk memenuhi permintaan energinya, dengan $87 \%$ dari total impor minyak mentah berasal dari Timur Tengah. Saat ini, Korea Selatan sedang berusaha untuk mendiversifikasi sumber energinya, termasuk dengan gas alam, yang sebagian besar juga masih bergantung pada impor. Oleh karena itu, potensi sumber daya alam di sekitar Dokdo atau Takeshima adalah suatu alternatif yang menarik. Selain adanya potensi keberadaan gas alam, wilayah tersebut juga kaya akan sumber daya pangan yang beragam, yaitu biota-biota laut seperti kod, pollock alaska, sauri pasifik, cumi-cumi, dan hiu. ${ }^{5}$

Hingga hari ini, secara de facto, Kepulauan Dokdo atau Takeshima berada dalam kontrol Republik Korea. Walaupun kepulauan tersebut sebenarnya tidak layak ditempati karena faktor ukuran yang kecil, pemerintah Korea mengizinkan dua orang warga negara biasa (nelayan) untuk tinggal di sana, serta menempatkan unit penjaga lepas pantai di kepulauan tersebut. ${ }^{6}$ Selain itu, pemerintah Republik Korea juga membangun beberapa bangunan dan insfrastruktur di kepulauan tersebut. Republik Korea juga menyatakan klaim penguasaan atas laut teritorial selebar 12 mil laut di sekitar Kepulauan Dokdo atau Takeshima. ${ }^{7}$

Di lain pihak, Jepang menyatakan bahwa posisinya tidak akan pernah berubah, yaitu bahwa Kepulauan Dokdo atau Takeshima adalah bagian yang tetap dan tak terpisahkan dari wilayah Jepang. Bagi negara tersebut, klaim yang dilakukan oleh Republik Korea merupakan sesuatu yang ilegal dan tidak berdasar menurut hukum internasional. ${ }^{8}$ Selain itu, pada 2008, Pemerintah Jepang juga sempat menerbitkan buku panduan mengajar untuk sekolah menengah, yang isinya memasukkan Dokdo atau Takeshima sebagai bagian dari Jepang. ${ }^{9}$ Belum lagi, pemerintah Prefektur Shimane, yang memiliki kewenangan atas Dokdo atau Takeshima menurut Jepang, telah mengumumkan secara publik tentang pengadaan "Takeshima Day".10 Pemerintah Jepang sendiri juga telah mengajukan kepada Republik Korea untuk menyelesaikan sengketa ini melalui Mahkamah Internasional, dan membuktikan klaimnya masing-masing. Tetapi, pemerintah Korea dengan tegas menolak permintaan tersebut. Pemerintah Republik

\footnotetext{
Ibid.

6 Hahm, S.D., \& Heo, U. (2019). History and Territorial Disputes, Domestic Politics, and International Relations: An Analysis of the Relationship among South Korea, China, and Japan. Korea Observer, 50(1), 53-80. DOI: 10.29152/koiks.2019.50.1.53. h. 58.

7 Atanassova-Cornelis, E., Pardo, R.P., \& Pejsova, E. op. cit. h. 18.

8 Kim, H.M, \& Cho, J. (2011). A New Approach to a Territorial Dispute Involving a Former Colonizer-Colony Pair: The Case of the Dokdo/Takeshima Dispute between Korea and Japan. Korea Observer, 42(3), 431-459. h. 434.

$9 \quad$ Ibid.

$10 \quad$ Ibid. h. 435.
} 
Korea beralasan bahwa sudah tidak ada yang perlu disengketakan, karena Dokdo atau Takeshima adalah bagian yang tetap dan tak terpisahkan dari Korea. ${ }^{11}$

Hingga saat ini, sengketa wilayah atas Kepulauan Dokdo/Takeshima belum menemukan titik terang penyelesaian. Republik Korea dan Jepang sama-sama bersikeras bahwa merekalah penguasa yang sah dengan dasar argumentasinya masingmasing. Pada penelitian sebelumnya (state of the art), Bowman telah melakukan penelitian mengenai perlunya penyelesaian sengketa Kepulauan Dokdo atau Takeshima. Bowman menyatakan bahwa ada 3 (tiga) pilihan pendekatan yang dapat dilakukan untuk menghadapi sengketa Kepulauan Dokdo atau Takeshima. Pertama, kedua negara dapat membiarkan sengketa yang ada tidak terselesaikan. Kedua, Republik Korea dapat menerima usulan Jepang untuk membawa sengketa ini ke Mahkamah Internasional. Ketiga, Negara-negara yang bersengketa tersebut dapat mengambil solusi dengan Jepang mengakui kedaulatan Korea atas Dokdo atau Takeshima, dan di sisi lain Jepang diberikan hak-hak tertentu untuk turut menikmati sumber daya yang ada di sekitar Dokdo atau Takeshima. ${ }^{12}$ Lebih lanjut, Bowman menyatakan bahwa pilihan yang ketiga adalah pilihan yang terbaik. Dengan pilihan ketiga tersebut, Bowman berpendapat bahwa hubungan Korea-Jepang dapat segera diperbaiki dan ketegangan relasi keduanya dapat menurun. ${ }^{13}$ Selain itu, Bowman berpandangan bahwa setidaknya ada 3 (tiga) penyebab mengapa pilihan pertama dan kedua tidak disarankan, antara lain adanya kondisi politik di mana peran Tiongkok semakin meningkat di kawasan Asia, dan mengalahkan Amerika Serikat; adanya efek populisme dan nasionalisme Korea; dan putusan Mahkamah Internasional atau Arbitrase yang berkaitan dengan kedaulatan umumnya sulit ditegakkan. ${ }^{14}$ Akan tetapi, selain alasan-alasan tersebut, Bowman juga menyarankan untuk dilakukan penyelesaian sengketa dengan cara ketiga, sebab menurutnya Jepang pada posisi yang lemah untuk mengklaim Dokdo atau Takeshima. ${ }^{15}$

Berangkat dari pernyataan tersebut, bahwa Jepang berada pada posisi yang lemah daripada Korea, maka penelitian ini bertujuan untuk menelaah klaim Jepang dan Republik Korea terhadap Dokdo atau Takeshima. Penelitian ini akan menelaah klaim dan argumentasi dari kedua negara, terutama dari klaim historis yang ada, serta menganalisisnya berdasarkan prinsip dan sudut pandang hukum internasional. Selain itu, secara khusus, penelitian ini juga akan menggunakan preseden yang berkaitan dengan sengketa wilayah yang pernah melibatkan wilayah Indonesia atau Hindia Belanda, serta menelaahnya bila dikaitkan dengan sengketa Kepulauan Dokdo atau Takeshima.

\section{Metode Penelitian}

Kata metode berasal dari bahasa Yunani, methodos, yang berarti suatu cara atau jalan. Penelitian adalah suatu kegiatan yang seringkali bermula dari rasa ingin tahu untuk menemukan jawaban atas suatu permasalahan faktual. Dengan demikian, metode

11 Lee, S., \& Dyke, J.M.V. Op. Cit. h. 753-754.

12 Bowman, G. (2013). Why Now Is the Time to Resolve the Dokdo/Takeshima Dispute. Case Western Reserve Journal of International Law, 46(1), 433-462. h. 436

13 Ibid.

14 Ibid. h. 443-449

15 Ibid. h. 451 
penelitian dapat diartikan sebagai suatu cara untuk mememecahkan suatu masalah atau mengembangkan suatu bidang ilmu dengan metode ilmiah. ${ }^{16}$ Dalam penelitian hukum dikenal beberapa metode penelitian, salah satunya adalah penelitian hukum normatif. Penelitian hukum normatif ialah suatu penelitian yang dilakukan dengan meneliti data sekunder atau bahan kepustakaan. ${ }^{17}$

Dalam penelitian hukum normatif dikenal beberapa pendekatan. Pertama, pendekatan sejarah yang berdasarkan pada pemahaman bahwa hukum pada masa lampau merupakan suatu kesatuan dan berhubungan erat, sambung-menyambung tak terputus dengan hukum di masa kini. Pendekatan sejarah sendiri dapat diartikan sebagai suatu pendekatan yang memungkinkan untuk menelaah latar belakang historis terjadinya suatu sistem atau lembaga, serta suatu pengaturan hukum tertentu. ${ }^{18}$ Kedua, pendekatan kasus yang dilakukan dengan menelaah pertimbangan-pertimbangan yang dilakukan mahkamah hingga menghasilkan suatu putusan. ${ }^{19}$ Ketiga, pendekatan konseptual yang dilakukan dengan menelaah pandangan dan doktrin dalam ilmu hukum..$^{20}$ Dengan demikian, berdasarkan penjabaran tersebut, maka penelitian hukum dalam tulisan ini merupakan penelitian hukum normatif dengan pendekatan sejarah, kasus, dan konseptual.

\section{Hasil Dan Pembahasan}

\subsection{Argumentasi Pihak Jepang}

Jepang berargumen bahwa Dokdo atau Takeshima telah berada di bawah kedaulatan Jepang sejak abad ke-17, dengan adanya catatan mengenai keberadaan beberapa keluarga nelayan Jepang yang menangkap ikan di perairan sekitar Dokdo atau Takeshima. $^{21}$ Jepang mengklaim bahwa Dokdo atau Takeshima adalah pulau penunjang dari pulau Oki. Jepang berpendapat bahwa pada waktu itu Korea telah mengabaikan Dokdo atau Takeshima, sehingga Jepang mengambil alih kontrol atas wilayah tersebut. ${ }^{22}$

Kemudian, dalam pandangan Jepang, tahun 1905 adalah waktu penggabungan Dokdo atau Takeshima secara formal ke dalam wilayah Jepang. Jepang mengklaim bahwa Dokdo atau Takeshima merupakan wilayah terra nullius atau wilayah yang belum diklaim oleh siapapun. Hal ini dibuktikan dengan tidak adanya pengajuan keberatan atau protes terhadap tindakan Jepang oleh pemerintah di Korea kala itu. ${ }^{23}$ Saat Jepang berperang melawan Rusia, pemerintah Jepang juga pernah membangun menara pengawas di kepulauan tersebut. Selanjutnya, pada bulan Februari 1905, gubernur

16 Efendi, J., \& Ibrahim, J. (2016). Metode Penelitian Hukum Normatif dan Empiris. Jakarta: Prenamedia Group, h. 2-3.

17 Efendi, J., \& Ibrahim, J. op. cit. h. 129-130.

18 Efendi, J., \& Ibrahim, J. op. cit. h. 144.

19 Marzuki, P.M. (2005). Penelitian Hukum: Edisi Revisi. Jakarta: Kencana, h. 133-136.

20 Ibid.

21 Hahm, S.D., \& Heo, U. loc. cit.

22 Kim, H.M, \& Cho, J. op. cit. h. 439.

23 Hahm, S.D., \& Heo, U. loc. cit. 
Prefektur Shimane menyatakan bahwa kepulauan tersebut disebut dengan nama "Takeshima". 24

Selain itu, Jepang juga mendasarkan argumennya pada Perjanjian San Fransisco 1951. Perjanjian tersebut telah menjadi sumber utama perdebatan dalam sengketa Dokdo atau Takeshima. ${ }^{25}$ Setelah Jepang dikalahkan dalam Perang Dunia II, Semenanjung Korea dan Jepang berada dalam pendudukan pihak sekutu, terutama Amerika Serikat. Pada 8 September 1951, ditandatanganilah Perjanjian Damai San Fransisco 1951 sebagai perjanjian damai antara Jepang dan pihak sekutu. Salah satu bunyi pasal dari perjanjian tersebut, yaitu pada pasal 2 huruf a, menyatakan bahwa Jepang mengakui kemerdekaan Korea, dan melepaskan semua hak dan klaim atas Korea, termasuk pulau Quepart, Port Hamilton, dan Dagelet (Ulleung). Jepang beragurmen bahwa Dokdo atau Takeshima tidak pernah dicantumkan dalam perjanjian tersebut, sehingga dengan demikian Jepang menganggap bahwa dirinya masih penguasa yang sah atas kepulauan tersebut. ${ }^{26}$

Belum lagi, bila melihat pada sejarah penyusunan Perjanjian San Fransisco 1951. Dari konsep awal hingga teks akhir yang digunakan, tampak bahwa pihak sekutu mengubah pikiran mereka beberapa kali perihal Dokdo atau Takeshima. Lima teks konsep awal yang pertama dan teks konsep yang ketujuh mencantumkan Dokdo sebagai salah satu wilayah yang harus dikembalikan pada Korea. Sedangkan, teks konsep yang keenam, kedelapan, kesembilan, dan keempat belas secara eksplisit mencantumkan Dokdo atau Takeshima sebagai wilayah Jepang. Tetapi, teks konsep yang kesepuluh, ketiga belas, kelima belas hingga kedelapan belas, dan teks akhir yang digunakan, semuanya diam perihal status Dokdo. ${ }^{27}$

\subsection{Argumentasi Pihak Republik Korea}

Melihat pada bukti sejarah yang ada, Republik Korea berargumen bahwa Kepulauan Dokdo telah menjadi bagian yang tak terpisahkan dari Korea sejak dari semula. Berdasarkan catatan yang dibuat oleh Chi Jung Wang dari Dinasti Silla, Samkuk-Sagi atau Kronik Tiga Kerajaan, yang diterbitkan pada tahun 114528, mencatat bahwa Usan-guk telah ditaklukan oleh Kim Isabu dari Silla, pada tahun 512.29 Lebih lanjut lagi, dalam dua tulisan geografi, Sejong-Sillok Jiriji atau Riwayat Raja Sejong, yang terbit tahun 1454, dan Dong'guk Yeoji Seungnam atau Geografi Korea, yang terbit tahun 1531, menyatakan bahwa Usan-guk merujuk pada Pulau Ulleung dan Dokdo di masa kini. ${ }^{30}$

Selain itu, menjelang akhir abad 17, seorang Korea bernama An Yong-bok menerima sebuah dokumen pemerintah pusat Jepang kala itu, Tokugawa bakufu, yang memberikan konfirmasinya bahwa Dokdo adalah milik Korea. ${ }^{31}$ Lebih lagi, pada 1696, pemerintah Jepang kala itu kemudian melarang adanya kegiatan nelayan di wilayah Dokdo yang telah diakui sebagai milik Korea. ${ }^{32}$ Selama kurun waktu 1870 - 1880, pandangan

24 Schwartz, T., \& Yoo, J. op. cit. h. 506.

25 Ibid. h. 506.

26 Kim, H.M, \& Cho, J. loc. cit.

27 Lee, S., \& Dyke, J.M.V. op. cit. h. 744-745.

28 Hahm, S.D., \& Heo, U. loc. cit.

29 Kim, H.M, \& Cho, J. op. cit. h. 437.

30 Ibid.

$31 \quad$ Ibid. h. 438.

32 Hahm, S.D., \& Heo, U. loc. cit. 
pemerintahan Meiji di Jepang juga tetap tak berubah. ${ }^{33}$ Kemudian, pada 1900, Kekaisaran Korea secara resmi mengumumkan bahwa Dokdo atau Takeshima secara resmi ditambahkan dalam wewenang pemerintah di Pulau Ulleung. ${ }^{34}$

Pada 2009, seorang peneliti dari Institut Maritim Korea telah menemukan dua dokumen pemerintah Jepang yang mengindikasikan pengakuan terhadap Dokdo atau Takeshima sebagai wilayah Korea. Dua dokumen tersebut ialah, Ordonansi Perdana Menteri nomor 24 (6 Juni 1951) dan Ordonansi Menteri Keuangan nomor 4 (13 Desember 1951). Kedua dokumen tersebut menyatakan bahwa Chejudo, Dokdo, dan Pulau Ulleung bukanlah termasuk wilayah Jepang. ${ }^{35}$ Selanjutnya, pada 2010, juga ditemukan dua buah peta buatan Jepang dari tahun 1877 dan 1889 yang dengan jelas menunjukkan bahwa Dokdo atau Takeshima bukanlah wilayah Jepang. Demikian pula, pada 2013, ditemukan dua buah peta buatan Tiongkok dari tahun 1845 dan 1851 yang menunjukkan bahwa Dokdo atau Takeshima berada dalam wilayah kekuasaan Kekaisaran Joseon, penguasa di Korea pada masa tersebut. ${ }^{36}$ Keberadaan dokumen-dokumen tersebut menunjukkan bahwa Korea adalah penemu dan penguasa Dokdo atau Takeshima yang sah, dan telah melakukan kontrol yang efektif secara kontinu di wilayah tersebut, baik sebelum 1905 dan sejak awal sekitar 1950.37

Bagi Korea, Dokdo atau Takeshima bukanlah bagian dari Jepang, tetapi merupakan wilayah Korea pertama yang diduduki oleh Jepang sebagai tempat awal sebelum melakukan invasi terhadap Semenanjung Korea. ${ }^{38}$ Dalam konteks tersebut, klaim Korea terhadap Dokdo juga berkaitan dengan kebanggaan sebagai suatu bangsa. Bila Jepang berhasil mengambil sejengkal tanah Dokdo atau Takeshima, hal tesebut dapat menjadi suatu hinaan bagi bangsa Korea. ${ }^{39}$

Terhadap argumentasi Jepang yang menyatakan bahwa tidak adanya perlawanan di tahun 1905 terhadap tindakan Jepang, Korea menganggap bahwa alasan ersebut merupakan suatu alasan yang tidak dapat diterima. Hal tersebut mengingat bahwa pada waktu itu Korea tidak memiliki kekuatan dan militer yang cukup untuk berlawanan dengan Jepang. ${ }^{40}$ Korea berpandangan bahwa invasi terhadap Dokdo atau Takeshima merupakan langkah awal dari usaha untuk melakukan kolonisasi terhadap Semenanjung Korea. Hal tersebut dibuktikan dengan dijadikannya Semenanjung Korea sebagai protektorat dari Jepang pada tahun 1905I dengan lahirnya Perjanjian Eulsa Tahun 190541, hingga akhirnya Jepang berhasil melakukan aneksasi secara formal terhadap Korea di tahun 1910 dengan lahirnya Perjanjian Jepang-Korea Tahun 1910.42

33 Schwartz, T., \& Yoo, J. op. cit. h. 507.

Ibid. h. 506.

35 Hahm, S.D., \& Heo, U. op. cit. h. 59-60.

36 Ibid.

37 Schwartz, T., \& Yoo, J. loc. cit.

38 Atanassova-Cornelis, E., Pardo, R.P., \& Pejsova, E. op. cit. h. 32.

39 Kim, H.M, \& Cho, J. op. cit. h. 441.

40 Bowman, G. loc. cit.

41 Ismail, A. (2017). The Dokdo / Takeshima Dispute: Responses And Approaches. International Journal of East Asian Studies, 6(1), 82-99, h. 83.

42 Ibid. 


\subsection{Telaah terhadap Klaim Wilayah Terra Nullius}

Dalam argumentasinya, Jepang berpandangan bahwa pihaknya adalah yang berhak atas Dokdo atau Takeshima, karena pada tahun 1905 wilayah Dokdo atau Takeshima dipandang sebagai sebagai wilayah terra nullius yang kemudian diduduki oleh Jepang. Yang dimaksud dengan wilayah terra nullius adalah suatu wilayah yang tidak dimiliki oleh siapapun. ${ }^{43}$ Dalam hal tersebut, Jepang menganggap dirinya telah melakukan okupasi terhadap Dokdo atau Takeshima. Okupasi merupakan bentuk perolehan kedaulatan atas wilayah yang belum pernah diletakkan di bawah kedaulatan suatu negara lain. ${ }^{44}$ Dengan demikian, Jepang menganggap bahwa dirinya telah memperoleh Dokdo atau Takeshima dengan sah, karena wilayah tersebut belum berada dalam kedaulatan pihak manapun sebelumnya.

Namun, fakta-fakta yang ada menunjukkan bahwa Dokdo atau Takeshima bukanlah suatu wilayah terra nullius. Hal tersebut sebagaimana yang dapat dilihat pada faktafakta sejarah, keberadaan peta-peta, dokumen-dokumen, dan bahkan dalam dokumen yang dikeluarkan oleh pemerintah Jepang sendiri, sebagaimana yang telah dijelaskan di bagian argumentasi pihak Republik Korea sebelumnya. Belum lagi, hal tersebut telah dipertegas dengan adanya bukti keberadaan pengumuman secara resmi oleh Kekaisaran Korea, pada tahun 1900, yang menyatakan bahwa wilayah Dokdo atau Takeshima dimasukkan dalam wewenang pemerintah di Pulau Ulleung. Dapat dilihat, bahwa telah terjadi klaim dan kontrol wilayah yang dilakukan oleh Korea, bahkan lima tahun sebelum Jepang melakukan pendudukan, menjadikan Korea sebagai protektorat, serta akhirnya berujung pada aneksasi di tahun 1910.

Selain itu, setelah kekalahan Jepang dalam perang dunia II, dapat dilihat bahwa Dokdo atau Takeshima memang selalu berada dalam kontrol dan pemanfaatan Korea, bukan Jepang. Hal tersebut dapat dibuktikan dengan peristiwa yang terjadi pada 30 Juni 1948. Pada waktu itu, militer Amerika Serikat sedang melakukan latihan pengeboman di wilayah Dokdo atau Takeshima. Sejumlah 16 (enam belas) nelayan Korea yang sedang melaut di sekitar Dokdo atau Takeshima meninggal dan enam orang lainnya terluka akibat latihan militer tersebut. Pemerintah Republik Korea segera mengambil suatu tindakan untuk menanggapi insiden tersebut dan menolong warganya. ${ }^{45}$ Tampak dalam hal ini, bahwa pihak Korea dan masyarakatnya adalah pihak yang memanfaatkan serta mengontrol wilayah Dokdo atau Takeshima.

Kemudian, pemerintah Republik Korea sendiri telah menunjukkan kontrolnya yang efektif terhadap Kepulauan Dokdo atau Takeshima hingga saat ini. Pada tahun 1952, Syngman Rhee, presiden pertama Republik Korea, mengumumkan adanya Deklarasi Presiden mengenai Laut Teritorial. Dalam deklarasi tersebut, pemerintah Republik Korea menarik garis batas, yang terkadang juga disebut "garis perdamaian", antara Korea dan Jepang, dengan memasukkan Dokdo atau Takeshima ke dalam wilayah Republik Korea. Sejak saat itu, pemerintah Republik Korea dengan aktif menunjukkan

43 Rossi, C. (2015). A Unique International Problem': The Svalbard Treaty, Equal Enjoyment, and Terra Nullius: Lessons of Territorial Temptation from History. Washington Global Studies Law Review, 15(1), 93-136, h. 111.

44 Sefriani., loc. cit.

45 Lee, S., \& Dyke, J.M.V. loc. cit. 
kontrolnya yang efektif dan kontinu terhadap wilayah Dokdo atau Takeshima hingga saat ini. Pada 1953, pemerintah Republik Korea mendirikan sebuah monumen territorial, serta kemudian sebuah mercusuar pada 1954. Pada 1980, pemerintah mulai mengizinkan warga negara biasa untuk menempati wilayah Dokdo atau Takeshima. Selanjutnya, pemerintah Republik Korea juga membangun landasan helikopter, fasilitas radar, dan pelabuhan, dalam kurun waktu 1980 sampai 2000.46 Lebih lagi, pada 2005, pemerintah Korea mengizinkan turis untuk mengunjungi Dokdo atau Takeshima yang dipromosikan sebagai simbol Korea. ${ }^{47}$

Selain itu, fakta geografis menunjukkan bahwa jarak antara Kepulauan Dokdo dan wilayah Republik Korea (Pulau Ulleung), lebih dekat di bandingkan dengan Jepang (Pulau Oki). Hal tersebut juga tentu menjadi suatu nilai tambah yang mendukung argumentasi Republik Korea. Posisi yang lebih dekat dengan Korea dapat menjadi suatu bukti bahwa Korea sejak dari semula sesuai dengan fakta sejarah yang ada, memiliki kemampuan untuk melakukan kontrol dan pemanfaatan yang efektif di Kepulauan Dokdo atau Takeshima. ${ }^{48}$

Berdasarkan fakta-fakta tersebut, maka sejatinya Republik Korea adalah pihak yang berhak untuk memiliki kedaulatan atas Kepulauan Dokdo atau Takeshima. Fakta-fakta tersebut menunjukkan bahwa Korea sejak dahulu telah menjalankan kontrol efektif terhadap Kepulauan Dokdo atau Takeshima. Hal tersebut tidak saja mematahkan klaim terra nullius yang dikemukakan Jepang, namun juga menunjukkan bahwa prinsip efektivitas telah dipenuhi oleh Korea.

Menurut pasal 38 ayat 1 huruf c Statuta Mahkamah Internasional disebutkan, bahwa salah satu sumber hukum internasional ialah prinsip-prinsip hukum umum yang diakui oleh bangsa-bangsa yang beradab. Dalam hukum kebiasaan internasional modern, suatu wilayah dikuasai oleh suatu negara yang dapat menunjukkan kemampuan untuk melakukan kontrol efektif terhadap wilayah tersebut. ${ }^{49}$ Hal inilah yang disebut prinsip efektivitas atau prinsip effective possession. Prinsip ini juga telah digunakan dalam memutus sengketa wilayah antar negara, seperti pada kasus Sipadan - Ligitan dan kasus Pulau Palmas.50

Kasus Sipadan - Ligitan merupakan kasus sengketa wilayah antara Indonesia dan Malaysia mengenai 2 (dua) pulau, yaitu Pulau Sipadan dan Pulau Ligitan, yang terletak di Laut Sulawesi. Pulau Sipadan terletak 14 mil di selatan daratan Sabah, Malaysia dan 42 mil di timur Pulau Sebatik, Indonesia. Pulau Ligitan terletak 12 mil di timur Pulau Sipadan. ${ }^{51}$ Sengketa atas Pulau Sipadan dan Ligitan mulai mencuat pada tahun 1969, ketika Indonesia dan Malaysia terlibat perundingan untuk membahas batas landas kontinen kedua negara. Kemudian, Pulau Sipadan dan Ligitan mendapatkan perhatian publik pada tahun 1979, ketika Malaysia mengeluarkan sebuah peta yang diberi nama

46 Kim, H.M, \& Cho, J. op. cit. h. 438.

47 Bowman, G. op. cit. h. 440.

$48 \quad$ Ibid. h. 453.

49 Bowman, G. op. cit. h. 452.

50 Sefriani. (2018). Hukum Internasional Suatu Pengantar. Depok: Rajawali Pers, h. 175.

51 Butcher, J. (2013). The International Court of Justice and the Territorial Dispute between Indonesia and Malaysia in the Sulawesi Sea. Contemporary Southeast Asia, 35(2), 235-257, DOI: 10.1355/cs35-2e, h. 237. 
"Peta Baru Menujukkan Sempadan Perairan dan Pelantar Benua Malaysia". Peta tersebut memasukkan Pulau Sipadan dan Pulau Ligitan sebagai wilayah Malaysia. ${ }^{52}$ Akhirnya, pada tahun 1996, Presiden Soeharto dari Indonesia dan Perdana Menteri Mahathir Mohammad dari Malaysia bersepakat untuk menyelesaikan sengketa ini melalui Mahkamah Internasional. 53

Dalam putusan kasus Sovereignty over Pulau Ligitan and Pulau Sipadan (Indonesia/Malaysia), Mahkamah Internasional memutuskan bahwa Malaysia adalah pemilik sah Pulau Sipadan dan Pulau Ligitan, atas dasar effectivités atau prinsip efektivitas. Mahkamah menemukan bahwa otoritas kolonial di Borneo Utara telah mengatur perihal pengumpulan telur penyu di Pulau Sipadan sejak tahun 1917, dan bahkan pada waktu-waktu setelahnya, juga telah membangun mencusuar di Pulau Sipadan dan Ligitan. ${ }^{54}$

Selain itu, jauh sebelum kasus Sipadan-Ligatan, pada era kolonial Belanda, juga pernah terjadi sengketa wilayah yang melibatkan wilayah Hindia Belanda di masa itu. Pada tahun 1928, Belanda pernah terlibat sengketa dengan Amerika Serikat, hingga sengketa tersebut dibawa ke Permanent Court of Arbitration atau Mahkamah Arbitrase Internasional. Sengketa tersebut ialah mengenai sebuah Pulau bernama Palmas, atau yang sekarang lebih dikenal sebagai Pulau Miangas. Pulau Miangas pada masa kini terletak dan merupakan perbatasan terluar Indonesia dengan Filipina. ${ }^{55}$ Amerika Serikat mendasarkan klaimnya atas Pulau Palmas dengan berdasarkan penemuan pulau oleh Spanyol pada abad ke-16, yang diikuti dengan adanya pengalihan hak Spanyol atas pulau tersebut kepada Amerika Serikat melalui Perjanjian Paris tahun 1898. Di sisi lain, Belanda mendasarkan klaimnya pada pendudukan yang efektif di pulau tersebut sejak abad ke-18. 56

Pada akhirnya, Mahkamah Arbitrase Internasional pada waktu itu memutuskan bahwa Belanda adalah pihak yang berhak atas Pulau Miangas. Titik tekan yang menjadi pertimbangan mahkamah pada waktu itu ialah, apakah Belanda menunjukkan kedaulatannya atas Pulau Palmas secara efektif, berkelanjutan, dan damai? Dalam hal tersebut, mahkamah menilai bahwa klaim Belanda adalah berdasar karena Belanda terbukti menunjukkan dan menerapkan otoritasnya di Pulau Palmas secara berkelanjutan. ${ }^{57}$

52 Ibid. h. 237-239

53 Hendrapati, M., et al. (2017). Today's Ambalat: Neglecting the Basepoints of Sipadan and Ligitan Islands for Maintaining the Equidistance Principle in the Disputed Area. Journal of East Asia and International Law, 10(1), 283-296, DOI:10.14330/jeail.2017.10.1.13, h. 283.

54 Huh, S. (2015). Title to Territory in the Post-Colonial Era: Original Title and Terra Nullius in the ICJ Judgments on Cases Concerning Ligitan/Sipadan (2002) and Pedra Branca (2008). The European Journal of International Law, 26(3), 709-725, doi:10.1093/ejil/chv036, h. 720.

55 Frederik, W.A.P.G. (2011). Impacts of the Implementation of Border Crossing Area Agreement Between Indonesia and the Philippines at the Border of Miangas Island of North Celebes. Indonesian Journal of International Law. 9(1). 152-172. DOI: 10.17304/ijil.vol9.1.341. h. 158.

56 Wheatley, S. (2020). Revisiting the Doctrine of Intertemporal Law. Oxford Journal of Legal Studies. 1-26. https:// doi.org/10.1093/ojls/gqaa058. h.4.

57 Ørebech, P.T. (2016). Terra nullius, Inuit Habitation and Norse Occupation With Special Emphasis onthe 1933 East Greenland Case. Arctic Review on Law and Politics, 7(1), 20-41, http://dx.doi.org/10.17585/arctic.v7.262. h. 33. 
Atas dasar prinsip efektivitas, karena adanya perbuatan-perbuatan yang menunjukkan effective possession terhadap Pulau Sipadan dan Ligitan oleh pemerintah kolonial Inggris, maka Malaysia sebagai negara suksesor dinilai sebagai pihak yang berhak atas Pulau Sipadan dan Ligitan. Demikian pula Belanda dinyatakan sebagai yang memiliki kedaulatan atas Pulau Palmas karena pihaknya terbukti melaksanakan kedaulatan dan otoritasnya terhadap pulau tersebut secara efektif dan kontinu. Dengan demikian, dengan adanya fakta-fakta bahwa adanya perbuatan-perbuatan kontrol efektif yang dilakukan Korea terhadap Kepulauan Dokdo atau Takeshima, bahkan sebelum Jepang menganeksasi Kepulauan Dokdo atau Takeshima, maka atas dasar prinsip efektivitas, dapat disimpulkan bahwa Korea memang berhak atas Kepulauan Dokdo atau Takeshima.

Pada akhirnya, doktrin terrra nullius yang ingin dipertahankan oleh Jepang tidaklah dapat digunakan untuk mempertahankan Dokdo atau Takeshima sebagai wilayah Jepang. Fakta-fakta yang ada lebih mendukung klaim Republik Korea, bahwa Kepulauan Dokdo atau Takeshima merupakan milik pihaknya. Dengan demikian, kekalahan Jepang dalam perang dunia kedua juga berarti bahwa Jepang seharusnya melepaskan wilayah-wilayah yang ditaklukannya, termasuk Dokdo atau Takeshima. Hal tersebut sebagaimana yang diserukan dalam Deklarasi Kairo 1943, yaitu untuk Jepang melepaskan kekuasannya atas wilayah-wilayah yang diperoleh dengan kekuatan. Hal tersebut dilakukan sebagai bagian dari usaha pemulihan keadaan status quo, seperti saat sebelum tindakan penaklukan oleh Jepang. 58

Deklarasi Kairo 1943 merupakan deklarasi yang dibuat bersama oleh Amerika Serikat, Inggris, dan Republik Tiongkok dalam suasana Perang Dunia Kedua. Ketiga negara tersebut menyatakan bahwa mereka akan berjuang dalam peperangan yang ada untuk menahan dan menghukum tindakan agresi yang dilakukan oleh Jepang. ${ }^{59}$ Selain itu, ketiga negara tersebut mendeklarasikan bahwa mereka akan melucuti kekuasaan Jepang dari semua pulau di Pasifik yang telah direbut atau diduduki sejak awal Perang Dunia Pertama di tahun 1914.60

Akan tetapi, Jepang berpandangan bahwa Deklarasi Kairo 1943 tidak dapat dijadikan dasar bahwa Kepulauan Dokdo atau Takeshima adalah milik Korea atau setidaknya harus dikembalikan kepada Korea, karena adanya beberapa alasan. Alasan pertama, Deklarasi Kairo menyebutkan bahwa kekuasan Jepang yang akan dilucuti ialah wilayah yang telah direbut atau diduduki sejak awal Perang Dunia Pertama. Sedangkan aneksasi Jepang terhadap Kepulauan Dokdo atau Takeshima dilakukan pada tahun 1905, beberapa waktu sebelum Perang Dunia Pertama terjadi. ${ }^{61}$ Kedua, Kepuluan Takeshima atau Dokdo tidak disebutkan secara eksplisit dalam Deklarasi Kairo 1943 sebagai wilayah yang harus dilepaskan oleh Jepang. ${ }^{62}$

58 Mayali, L., \& Yoo, J. (2018). Resolution of Territorial Disputes in East Asia: The Case of Dokdo. Berkeley Journal of International Law, 36(3), 504-550. DOI: 10.15779/Z38HT2GC0Q. h. 547

59 Ibid.

60 Ibid.

61 Ibid.

62 Akimoto, D. (2020). Takeshima or Dokdo? Toward Conflict Transformation of the JapanKorea Territorial Dispute. Asian-Pasific Law \& Policy Journal, 22(1), 51-89. h. 68-69. 
Walaupun Jepang berpendapat demikian, namun faktanya Deklarasi Kairo 1943 tidak berhenti sebatas itu. Dalam Deklarasi Kairo 1943 juga disebutkan, bahwa "Jepang juga akan diusir dari semua wilayah lain yang telah direbutnya dengan kekerasan dan keserakahan (violence and greed)".63 Lebih lanjut dideklarasikan, bahwa ketiga negara tersebut tetap "memperhatikan perbudakan rakyat Korea" dan mereka "bertekad bahwa pada waktunya Korea akan merdeka". ${ }^{64}$ Dengan demikian, Deklarasi Kairo nyatanya tidak hanya berhenti pada wilayah-wilayah yang diperoleh sejak Perang Dunia Pertama maupun wilayah-wilayah yang disebutkan secara eksplisit di dalam Deklarasi tersebut, sebagaimana argumentasi Jepang.

Setelah kekalahan Jepang dalam Perang Dunia Kedua, Jepang hanya mengakui dan menerima ketentuan-ketentuan dalam Deklarasi Kairo 1943 secara terbatas. Misalnya, untuk wilayah di Asia Timur, Jepang menerima ketentuan bahwa pihaknya akan dilucuti dari kekuasaannya terhadap wilayah yang telah diambil dari orang-orang Tiongkok, seperti Manchuria, Formosa, dan Pescadores, yang mana wilayah-wilayah tersebut akan dikembalikan kepada Tiongkok. ${ }^{65}$

\subsection{Telaah terhadap Klaim Wilayah Berdasarkan Perjanjian San Fransisco 1951}

Setelah berakhirnya perang dunia kedua dengan kekalahan Jepang, pihak sekutu mengambil alih kekuasaan atas Semenanjung Korea dan Jepang. Pada 8 September 1951, diadakanlah perjanjian damai antara Jepang dan pihak sekutu, yang juga disebut sebagai Perjanjian San Fransisco 1951. Dalam pasal 2 huruf a perjanjian tersebut disebutkan, bahwa Jepang mengakui kemerdekaan Korea, serta melepaskan semua hak dan klaimnya atas Korea, termasuk pulau Quepart, Port Hamilton, dan Dagelet atau Ulleung. Dokdo atau Takeshima tidaklah disebutkan secara eksplisit dalam perjanjian tersebut, sehingga Jepang menganggap bahwa Jepang tidak perlu melepaskan hak kekuasaannya atas kepulauan tersebut.

Dalam perkembangan masa kini, isu wilayah semacam ini tentu tidaklah cukup bila hanya melihat pada Perjanjian San Fransisco 1951, tanpa memperhatikan konteks bahwa Jepang telah menganeksasi Semenanjung Korea pada awal abad 20.66 Selain itu, argumentasi Jepang sebenarnya kurang dapat diterima kalau hanya karena ketiadaan penyebutan eksplisit Dokdo atau Takeshima. Bila melihat pada Perjanjian San Fransisco 1951, perjanjian tersebut juga hanya menyebutkan tiga pulau dari total 3.215 pulau yang sebenarnya milik Korea, sehingga alasan ketiadaan penyebutan secara eksplisit kurang dapat diterima. ${ }^{67}$

63 Mayali, L., \& Yoo, J., loc. cit.

64 Ibid.

65 Baldacchino, G. (2016). Diaoyu Dao, Diaoyutai or Senkaku? Creative solutions to a festering dispute in the East China Sea from an 'Island Studies' perspective. Asia Pasific Viewpoint, 57(1), 16-26. ISSN 1360-7456. h. 17.

66 Lee, S. (2011). Dokdo: The San Fransisco Peace Treaty, International Law on Territorial Disputes, and Historical Criticism. Asian Perspective, 35(5), 361-380. DOI: 10.1353/apr.2011.0003. h. 361.

67 Lee, S., \& Dyke, J.M.V. loc. cit. 
Kemudian, bila melihat pada pandangan awal para sekutu yang memegang kontrol atas Jepang dan Semenanjung Korea setelah kekalahan Jepang di Perang Dunia kedua, memberikan implikasi bahwa pihak sekutu berpandangan bahwa Dokdo atau Takeshima adalah bagian dari wilayah Korea. Hal tersebut didukung dengan dikeluarkannya Supreme Commander of Allied Powers' Instruction Note (SCAPIN). SCAPIN merupakan petunjuk operasional yang dikeluarkan oleh pihak sekutu. Pada 1946, pihak sekutu mengeluarkan SCAPIN nomor 677 dengan judul "Govermental and Administrative Separation of Certain Outlying Areas from Japan" atau "Pemisahan Pemerintahan dan Administratif dari Daerah Terluar Tertentu dari Jepang", yang tidak mencantumkan Kepulauan Dokdo atau Takeshima sebagai wilayah Jepang. Paragraf 3 (tiga) SCAPIN nomor 677 tersebut mengatur bahwa wilayah Jepang ialah mencakup 4 (empat) pulau utama Jepang (Hokkaido, Honshu, Kyushu, dan Shikoku), serta sekitar 1000 pulau kecil yang berdekatan, termasuk Kepulauan Tsushima dan Kepulauan Ryukyu. Wilayah yang tidak termasuk antara lain Pulau Ullung, Liancourt Rocks (atau Kepulauan Dokdo), dan Pulau Quelpart (atau Pulau Jeju). ${ }^{6}$ Setahun setelahnya, pihak sekutu juga kembali mengeluarkan SCAPIN nomor 1033 yang kali ini lebih tegas menyatakan, bahwa Kepulauan Dokdo atau Takeshima bukan termasuk wilayah Jepang. SCAPIN nomor 1033 tersebut mengatur bahwa kapal-kapal Jepang dan awaknya dilarang mendekati pulau tersebut, maupun mendekati area selebar 12 mil laut dari Kepulauan Dokdo atau Takeshima. 69

Hal tersebut juga menunjukkan bahwa pihak sekutu, yang menyusun Perjanjian San Fransisco 1951, tidak mencantumkan Dokdo atau Takeshima dalam perjanjian karena adanya alasan tertentu. Anggapan pertama ialah, bahwa pihak sekutu pada akhirnya tidak mencapai konsensus mengenai status Dokdo atau Takeshima, sehingga melewatkannya begitu saja. ${ }^{70}$ Namun demikian, bila memperhatikan keberadaan SCAPIN tersebut, maka alasan yang juga mungkin mengenai pihak sekutu yang tidak mecantumkan nama Dokdo secara eksplisit dalam Perjanjian San Fransisco ialah bahwa Kepulauan Dokdo atau Takeshima telah diakui dari semula sebagai bagian dari Korea, sehingga hal tersebut tidak perlu diperdebatkan lagi atau dimasukkan ke dalam isi perjanjian.

Bagaimanapun juga, Perjanjian San Fransisco 1951 tidaklah cukup untuk dijadikan dasar klaim terhadap Dokdo atau Takeshima. Bila mengikuti alur berpikir Jepang, sebenarnya perjanjian tersebut juga tidak mengatur secara eksplisit bahwa Dokdo atau Takeshima sebagai wilayah yang tetap dikuasai Jepang. Kalaupun hal tersebut dicantumkan, Jepang tetap tidak akan mudah menegakkan perjanjian tersebut. Hal tersebut mengingat bahwa Republik Korea bukanlah negara pihak yang turut terlibat dan ambil bagian dalam perjanjian tersebut, sehingga tidak memiliki kewajiban untuk menaati perjanjian tersebut. ${ }^{71}$

\section{Kesimpulan}

68 Pak, H., \& Son, H. (2020)., Analysis On The Definition Of Japanese Territory After World War II In Terms Of International Law: The Southern Kurils, The Diaoyu Islands And Tok Islet. Russian Law Journal, 8(4), 30-52, https:// doi.org/10.17589/2309-8678-2020-8-4-30-52, h. 40.

69 Ismail, A. op. cit. h. 84.

70 Schwartz, T., \& Yoo, J. op. cit. h. 508.

71 Ibid. 
Wilayah adalah suatu kualifikasi yang penting bagi berdirinya sebuah negara. Oleh karena itu, sengketa wilayah antar negara adalah hal yang mungkin untuk terjadi. Hal tersebut adalah sebagaimana yang terjadi antara Republik Korea dan Jepang. Keduanya sama-sama menyatakan klaimnya atas Kepulauan Dokdo atau Takeshima yang terletak di perbatasan kedua negara. Keduanya memiliki dasar argumentasinya masing-masing untuk mendukung klaim mereka. Dalam pandangannya, Jepang berpendapat bahwa ia adalah penguasa yang sah, dengan alasan utama yaitu Dokdo atau Takeshima adalah wilayah terra nullius yang kemudian diokupasi. Selain itu, Jepang juga berpandangan bahwa Dokdo atau Takeshima tidak disebutkan dalam Perjanjian San Fransisco 1951. Di lain pihak, Republik Korea mendasarkan argumentasinya pada fakta-fakta sejarah dan kontrol efektif yang telah dilakukannya selama ini. Fakta-fakta dan dokumen-dokumen yang dikemukakan dan mendukung klaim Republik Korea bahkan ditemukan berasal dari sumber Jepang. Selain itu, Republik Korea juga mendasarkan argumentasinya pada kontrol efektif yang telah dilakukannya sekian waktu ini. Dengan adanya kontrol tersebut, maka atas dasar prinsip efektivitas dalam hukum internasional, maka klaim Republik Korea memiliki dasar yang kuat. Hal tersebut juga diperkuat dengan preseden-preseden sebelumnya seperti pada kasus Sipadan-Ligitan dan kasus Pulau Palmas. Dengan demikian, klaim Republik Korea lebih kuat daripada klaim Jepang, berdasarkan hukum internasional, bila memperhatikan argumentasi yang telah dikemukakan, fakta yang telah dipaparkan, preseden yang ada, dan tindakan yang telah dilakukan oleh Korea.

Sengketa wilayah meskipun merupakan hal lumrah yang dapat terjadi antar negara, namun tetap diperlukan penyelesaian sengketa untuk memelihara dan menjaga statbilitas serta perdamaian di kalangan masyarakat internasional. Penulis berharap bahwa kedepannya dapat dilakukan penelitian dan pembahasan lebih lanjut mengenai dasar klaim kedua negara dari segi lain, maupun melalui penemuan segi historis lainnya. Hal tersebut diharapkan dapat menjadi suatu sumbangan pemikiran bagi tercapainya penyelesaian sengketa Kepulauan Dokdo atau Takeshima. Selain itu, berkaca dari preseden yang ada, seperti kasus sengketa Sipadan-Ligitan dan kasus Pulau Palmas, dapat disimpulkan bahwa prinsip efektivitas merupakan dasar yang yang dapat digunakan oleh negara dalam memperkuat klaimnya terhadap suatu wilayah. Di sisi lain, preseden tersebut juga menunjukkan bahwa penyelesaian sengketa dengan melibatkan Mahkamah Internasional maupun Mahkamah Arbitrase Internasional merupakan beberapa cara yang dapat digunakan untuk menyelesaikan sengketa Kepulauan Dokdo atau Takeshima, agar sengketa yang ada dapat berakhir dan terciptanya kepastian hukum bagi para pihak. Akan tetapi, bila memungkinkan, penulis lebih menyarankan agar kiranya dapat ditemput cara-cara lain dalam penyelesaian sengketa yang ada. Hal tersebut juga berkaca dari preseden kasus Sipadan-Ligitan, bahwa penyelesaian sengketa internasional yang demikian akan menyebabkan adanya pihak yang dikalahkan atau adanya pihak yang mungkin merasa dirugikan. Oleh karena itu, penulis menyarankan agar penyelesaian sengketa internasional yang bersifat politis, seperti negosiasi maupun mediasi, dapat lebih diusahkakan dan diutamakan dalam penyelesaian sengketa Kepulauan Dokdo atau Takeshima. Dengan demikian, penyelesaian sengketa yang tercapai diharapkan dapat lebih menguntungkan dan memberikan rasa keadilan bagi para pihak yang ada. 


\section{Daftar Pustaka / Daftar Referensi}

\section{$\underline{\text { Buku }}$}

Atanassova-Cornelis, E., Pardo, R. P., \& Pejsova, E. (2015). Pride and Prejudice: Maritime Disputes in Northeast Asia. Paris: European Union Institute for Security Studies.

Ball, D., \& Tanter, R. (2015). The Tools of Owatatsumi: Japan's Ocean Surveillance and Costal Defence Capabilities. Canberra: ANU Press.

Efendi, J., \& Ibrahim, J. (2016). Metode Penelitian Hukum Normatif dan Empiris. Jakarta: Prenamedia Group

Marzuki, P.M. (2005). Penelitian Hukum: Edisi Revisi. Jakarta: Kencana.

Sefriani. (2018). Hukum Internasional Suatu Pengantar. Depok: Rajawali Pers.

\section{Jurnal}

Akimoto, D. (2020). Takeshima or Dokdo? Toward Conflict Transformation of the JapanKorea Territorial Dispute. Asian-Pasific Law \& Policy Journal, 22(1), 51-89.

Baldacchino, G. (2016). Diaoyu Dao, Diaoyutai or Senkaku? Creative solutions to a festering dispute in the East China Sea from an 'Island Studies' perspective. Asia Pasific Viewpoint, 57(1), 16-26. ISSN 1360-7456.

Bowman, G. (2013). Why Now Is the Time to Resolve the Dokdo/Takeshima Dispute. Case Western Reserve Journal of International Law, 46(1), 433-462.

Butcher, J. (2013). The International Court of Justice and the Territorial Dispute between Indonesia and Malaysia in the Sulawesi Sea. Contemporary Southeast Asia, 35(2), 235-257, DOI: 10.1355/cs35-2e.

Frederik, W.A.P.G. (2011). Impacts of the Implementation of Border Crossing Area Agreement Between Indonesia and the Philippines at the Border of Miangas Island of North Celebes. Indonesian Journal of International Law. 9(1). 152-172. DOI: 10.17304/ijil.vol9.1.341.

Hahm, S.D., \& Heo, U. (2019). History and Territorial Disputes, Domestic Politics, and International Relations: An Analysis of the Relationship among South Korea, China, and Japan. Korea Observer, 50(1), 53-80. DOI: 10.29152/koiks.2019.50.1.53

Hendrapati, M., et al. (2017). Today's Ambalat: Neglecting the Basepoints of Sipadan and Ligitan Islands for Maintaining the Equidistance Principle in the Disputed Area. Journal of East Asia and International Law, 10(1), 283-296, DOI:10.14330/jeail.2017.10.1.13.

Huh, S. (2015). Title to Territory in the Post-Colonial Era: Original Title and Terra Nullius in the ICJ Judgments on Cases Concerning Ligitan/Sipadan (2002) and Pedra Branca (2008). The European Journal of International Law, 26(3), 709-725, doi:10.1093/ejil/chv036

Ismail, A. (2017). The Dokdo /Takeshima Dispute: Responses And Approaches. International Journal of East Asian Studies, 6(1), 82-99.

Kim, H.M., \& Cho, J. (2011). A New Approach to a Territorial Dispute Involving a Former Colonizer-Colony Pair: The Case of the Dokdo/Takeshima Dispute between Korea and Japan. Korea Observer, 42(3), 431-459. 
Lee, S. (2011). Dokdo: The San Francisco Peace Treaty, International Law on Territorial Disputes, and Historical Criticism. Asian Perspective, 35(5), 361-380. DOI: 10.1353/apr.2011.0003

Lee, S., \& Dyke, J.M.V. (2010). The 1951 San Fransisco Peace Treaty and Its Relevance to the Sovereignty over Dokdo. Chinese Journal of International Law, 9(4), 741-762. DOI: 10.1093/chinesejil/jmq030

Mayali, L., \& Yoo, J. (2018). Resolution of Territorial Disputes in East Asia: The Case of Dokdo. Berkeley Journal of International Law, 36(3), 504-550. DOI: 10.15779/Z38HT2GC0Q.

Pak, H., \& Son, H. (2020). Analysis On The Definition Of Japanese Territory After World War II In Terms Of International Law: The Southern Kurils, The Diaoyu Islands And Tok Islet. Russian Law Journal, 8(4), 30-52, https://doi.org/10.17589/23098678-2020-8-4-30-52.

Rossi, C. (2015). A Unique International Problem': The Svalbard Treaty, Equal Enjoyment, and Terra Nullius: Lessons of Territorial Temptation from History. Washington Global Studies Law Review, 15(1), 93-136.

Schwartz, T., \& Yoo, J. (2019). Asian Territorial Disputes and the 1951 San Francisco Peace Treaty: The Case of Dokdo. Chinese Journal of International Law, 18(3), 503550. DOI: $10.1093 /$ chinesejil/jmz017.

Wheatley, S. (2020). Revisiting the Doctrine of Intertemporal Law. Oxford Journal of Legal Studies. 1-26. https:/ / doi.org/10.1093/ojls/gqaa058.

Ørebech, P.T. (2016). Terra nullius, Inuit Habitation and Norse Occupation With Special Emphasis onthe 1933 East Greenland Case. Arctic Review on Law and Politics, 7(1), 20-41, http://dx.doi.org/10.17585/arctic.v7.262.

\section{Konvensi, Perjanjian, Statuta, dan Peraturan}

Konvensi tentang Hak dan Tugas Negara (Montevideo, 26 Desember 1933)

Perjanjian Damai dengan Jepang (San Fransisco, 8 September 1951)

Statuta Mahkamah Internasional

Supreme Commander of Allied Powers' Instruction Note nomor 677

Supreme Commander of Allied Powers' Instruction Note nomor 1033 